\title{
Dyslipidemia in type 2 diabetes mellitus
}

\author{
Thapa Subarna Dhoj ${ }^{1}$, KC Shiva Raj ${ }^{2}$, Gautam Santosh ${ }^{1}$, Gyawali Deepika ${ }^{3}$ \\ ${ }^{\prime}$ Department of Medicine, KIST Medical College \& Teaching Hospital, Lalitpur, Nepal \\ ${ }^{2}$ Department of Pathology, KIST Medical College \& Teaching Hospital, Lalitpur, Nepal \\ ${ }^{3}$ KIST Medical College \& Teaching Hospital, Lalitpur, Nepal
}

\section{Keywords: \\ Cholesterol; \\ Diabetes; \\ Glucose; \\ Lipid profile; \\ Lipoprotein; \\ Triglyceride}

\author{
ABSTRACT \\ Background: In type 2 diabetes mellitus lipid abnormalities are very common and is associated with \\ increased risk of cardiovascular diseases. This study was conducted to find association of type 2 diabetes \\ and dyslipidemia.
}

Materials and Methods: This cross-sectional study was conducted at KIST medical college teaching hospital. All the necessary data of patient with type 2 diabetes in the period between December 2016 and May 2017 were studied.

Results: Out of 199 patients with diabetes mellitus $30.7 \%$ had total cholesterol $>200 \mathrm{mg} / \mathrm{dl}, 64.4 \%$ had elevated low density lipoprotein, 53.77\% patient had elevated triglyceride and 64\% patients had low high density lipoprotein level. Cholesterol showed significant correlation with triglyceride $(\mathrm{P}<0.001)$, low density lipoprotein $(\mathrm{P}<0.001)$. Triglyceride showed a significant negative correlation with high density lipoprotein $(\mathrm{P}<0.01)$, while a highly significant positive correlation was observed with cholesterol and high density lipoprotein $(\mathrm{P}<0.001)$.

Conclusion: Diabetes is associated with high incidence of dyslipidemia with elevated level of low density lipoprotein, cholesterol and triglyceride.
Correspondence:

Dr. Subarna Dhoj Thapa, MBBS, MD

Assistant Professor, Department of Medicine

KIST Medical College \& Teaching Hospital, Imadole, Lalitpur, Nepal.

ORCID ID: 0000-0002-2107-5322

Email: subarnadhoj@gmail.com

Received : June 2nd, 2017; Accepted : August 5th, 2017; Published : September 1, 2017

Citation: doi: Thapa SD, KC Shiva Raj, Gautam S, Gyawali D. Dyslipidemia in Type 2 Diabetes mellitus. 2017;7:1149-54. Doi 10.3126/jpn.v7i2.17978

Copyright: This is an open-access article distributed under the terms of the Creative Commons Attribution 4.0 International License, which permits unrestricted use, distribution, and reproduction in any medium, provided the original author and source are credited.

\section{INTRODUCTION}

Type 2 Diabetes Mellitus (T2DM) is associated with a marked increased risk of cardiovascular diseases (CVD). Individuals with T2DM have an absolute risk of major coronary events similar to that of non diabetic individual with established coronary heart disease (CHD). ${ }^{1}$ Furthermore, after an acute coronary event, diabetic subject develop congestive heart failure more frequently and have a higher mortality rate than non diabetic individual. ${ }^{2,3} \mathrm{~A}$ greater burden of risk factor is at least partly responsible for the increased risk of CHD in diabetes. Dyslipidemia is a well recognized and modifiable risk factor that should be identified early to institute aggressive cardiovascular preventive management.

In T2DM, lipid abnormalities are common. Typical findings 
Table 1: Gender distribution and age of selected type-2 diabetes patient

\begin{tabular}{l|lll}
\hline $\begin{array}{c}\text { Age group } \\
\text { (yrs) }\end{array}$ & Male (n) & Female (n) & Total (\%) \\
\hline $\mathbf{2 5 - 3 5}$ & 13 & 13 & $26(13.06)$ \\
\hline $\mathbf{3 6}-45$ & 30 & 25 & $55(27.63)$ \\
\hline $\mathbf{4 6 - 5 5}$ & 30 & 28 & $58(29.14)$ \\
\hline $\mathbf{5 6}-65$ & 17 & 15 & $32(16.08)$ \\
\hline $\mathbf{6 6}-\geq \mathbf{7 0}$ & 19 & 09 & $28(14.07)$ \\
\hline Total & $\mathbf{1 0 9}(\mathbf{5 4 . 7 7 \% )}$ & $\mathbf{9 0 ( 4 5 . 2 3 \% )}$ & $\mathbf{1 9 9}(\mathbf{1 0 0})$ \\
\hline
\end{tabular}

are elevation of total and VLDL cholesterol, triglyceride concentration, exaggerated postprandial lipidemia, lowering of HDL cholesterol and a predominance of small, dense LDL-C particles. ${ }^{4}$ Insulin resistance is often involved in this process. ${ }^{5}$

Hypertriglyceridemia has been associated with increased risk of coronary heart disease both in non diabetic and diabetic subjects. ${ }^{6,7}$ Remnants of triglyceride rich lipoproteins seem to be extremely atherogenic. ${ }^{8}$ Such dyslipidemia is related to life style factors such as diet and exercise. ${ }^{9}$ It also has association with metabolic syndrome. ${ }^{10}$ The Pro-atherogenic properties of small LDL particles may relate to their ability to penetrate the arterial wall and thereby making them more susceptible to oxidation, indirectly linked with coronary artery disease. ${ }^{11,12}$

Coronary artery disease represents a wide spectrum of atherosclerosis and includes angina pectoris, unstable angina, non ST elevation myocardial infarction, heart failure, ST elevation myocardial infarction and sudden death to silent myocardial ischemia. ${ }^{13}$ Silent myocardial ischemia has a reported prevalence of $10-20 \%$ in diabetic population as compared to $1-4 \%$ in non diabetic population. ${ }^{14}$

This study was conducted to evaluate the fasting lipid profile pattern in T2DM patients attending KISTMCTH, Lalitpur, Nepal.

\section{MATERIALS AND METHODS}

This study was conducted in department of Medicine and department of Pathology of KIST Medical College and Teaching Hospital, Lalitpur. All the medical files of patients with type 2 diabetes in the period between December 2016 and May 2017 were studied. Patients with known diabetics taking oral hypoglycaemic agents or managed with diet or using insulin for the glycaemic control were included in the study. Permission from the institutional review committee was obtained.

Data like height, weight, blood glucose level, serum lipid profile which included total cholesterol, low density lipoprotein cholesterol (LDL-C), high density lipoprotein cholesterol (HDL-C) and Triglyceride (TG) were recorded whenever possible in the proforma. BMI was calculated as weight in $\mathrm{kg}$ divided by square of height in meter. BMI of $<24.9 \mathrm{~kg} / \mathrm{m}^{2}$ was considered normal, $25-29.9 \mathrm{~kg} / \mathrm{m}^{2}$ as overweight and $\geq 30 \mathrm{~kg} / \mathrm{m}^{2}$ as obese. ${ }^{15}$ Classification of different components of serum lipid (total cholesterol, LDL cholesterol, triglyceride and HDL cholesterol) was followed according to the recommendation of NCEP ATP III. ${ }^{16}$

\section{RESULTS}

During the study period, a total of 199 cases were found in the medical record department. Among these patients mean age was 50.35 years with youngest being 26 years and oldest being 76 years of age. Most of the patients with type 2 diabetes were in the age group 46-55yrs $(29.14 \%)$ followed by $36-45 y$ rs age group $(27.63 \%)$. Most of the diabetic patients were male than female with male to female ratio of $1.21: 1$.

Weight and height were available in 100 patients of study population. Fifty per cent patients had normal BMI $(<24.9)$ whereas 28 patients $(28.0 \%)$ were overweight and 22 patients $(22.0 \%)$ were obese. Blood glucose levels were recorded and mean blood glucose level was $222.01 \mathrm{mg}$ /

Table 2: Blood glucose level at various age group

\begin{tabular}{|c|c|c|c|c|c|c|}
\hline \multirow{2}{*}{\multicolumn{2}{|c|}{ Age Group }} & \multicolumn{3}{|c|}{ Blood glucose (mg/dL) } & \multirow{2}{*}{ Total } & \multirow{2}{*}{$\begin{array}{l}\text { Mean blood glucose } \\
(\mathrm{mg} / \mathrm{dL})\end{array}$} \\
\hline & & \multirow{2}{*}{$\begin{array}{r}<125 \\
4(2.01 \%)\end{array}$} & \multirow{2}{*}{\begin{tabular}{r|}
$126-200$ \\
$5(2.51 \%)$
\end{tabular}} & \multirow{2}{*}{$\begin{array}{r}\geq 200 \\
4(2.01 \%)\end{array}$} & & \\
\hline \multirow{2}{*}{ 25-35 years } & $\mathrm{F}$ & & & & $13(6.53 \%)$ & \multirow{2}{*}{142.5} \\
\hline & M & $5(2.51 \%)$ & $7(3.51 \%)$ & $1(0.5 \%)$ & $13(6.53)$ & \\
\hline \multirow{2}{*}{$36-45$ years } & $\mathrm{F}$ & $3(1.5 \%)$ & $9(4.52 \%)$ & $13(6.53 \%)$ & $25(12.56 \%)$ & \multirow{2}{*}{268.2} \\
\hline & M & $7(3.51 \%)$ & $11(5.52 \%)$ & $12(6.03 \%)$ & $30(15.07 \%)$ & \\
\hline \multirow{2}{*}{ 46-55 years } & $\mathrm{F}$ & $6(3.01 \%)$ & $4(2.01 \%)$ & $18(9.04 \%)$ & $28(14.07 \%)$ & \multirow{2}{*}{233.3} \\
\hline & M & $4(2.01 \%)$ & $9(4.52 \%)$ & $17(8.54 \%)$ & $30(15.07 \%)$ & \\
\hline \multirow{2}{*}{ 56-65 years } & $\mathrm{F}$ & $3(1.5 \%)$ & $8(4.02 \%)$ & $4(2.01 \%)$ & $15(7.53 \%)$ & \multirow{2}{*}{193.1} \\
\hline & M & $2(1.0 \%)$ & $8(4.02 \%)$ & $7(3.51 \%)$ & $17(8.54 \%)$ & \\
\hline \multirow{2}{*}{$\geq 66$ years } & $\mathrm{F}$ & $3(1.5 \%)$ & $4(2.01 \%)$ & $2(1.0 \%)$ & $9(4.52 \%)$ & \multirow{2}{*}{217.8} \\
\hline & M & $2(1.0 \%)$ & $7(3.51 \%)$ & $10(5.02 \%)$ & $19(9.54 \%)$ & \\
\hline Total & & $39(19.59 \%)$ & $72(36.18 \%)$ & $88(44.22 \%)$ & $199(100 \%)$ & \\
\hline
\end{tabular}


Table 3: Total cholesterol level at various age groups in both sexes

\begin{tabular}{|c|c|c|c|c|c|c|}
\hline \multirow{2}{*}{\multicolumn{2}{|c|}{ Age Group }} & \multicolumn{3}{|c|}{ Total Cholesterol (mg/dL) } & \multirow{2}{*}{ Total } & \multirow{2}{*}{ Total Cholesterol (mg/dL) } \\
\hline & & $<125$ & $126-200$ & $\geq \mathbf{2 0 0}$ & & \\
\hline \multirow{2}{*}{ 25-35 years } & $\mathrm{F}$ & $8(4.02 \%)$ & 0 & $5(2.51 \%)$ & $13(6.53 \%)$ & \multirow{2}{*}{192.65} \\
\hline & M & $10(5.02 \%)$ & $2(1.0 \%)$ & $1(0.5 \%)$ & $13(6.53 \%)$ & \\
\hline \multirow{2}{*}{$36-45$ years } & $\mathrm{F}$ & $16(804 \%)$ & $6(3.01 \%)$ & $3(1.5 \%)$ & $25(12.56 \%)$ & \multirow{2}{*}{201.48} \\
\hline & M & $22(11.04 \%)$ & $6(3.01 \%)$ & $2(1.0 \%)$ & $30(15.07 \%)$ & \\
\hline \multirow{2}{*}{ 46-55 years } & $\mathrm{F}$ & $13(6.53 \%)$ & $10(5.02 \%)$ & $5(2.51 \%)$ & $28(14.07 \%)$ & \multirow{2}{*}{178.42} \\
\hline & M & $19(9.54 \%)$ & $9(4.52 \%)$ & $2(1.0 \%)$ & $30(15.07 \%)$ & \\
\hline \multirow{2}{*}{$56-65$ years } & $\mathrm{F}$ & $12(6.03 \%)$ & $3(1.5 \%)$ & 0 & $15(7.53 \%)$ & \multirow{2}{*}{170.81} \\
\hline & M & $14(7.03 \%)$ & $3(1.5 \%)$ & 0 & $17(8.54 \%)$ & \\
\hline \multirow{2}{*}{$\geq 66$ years } & $\mathrm{F}$ & $9(4.52 \%)$ & 0 & 0 & $9(4.52 \%)$ & \multirow{2}{*}{173.87} \\
\hline & M & $15(7.53 \%)$ & $4(2.01 \%)$ & 0 & $19(9.54 \%)$ & \\
\hline Total & & $138(69.3 \%)$ & $43(21.6 \%)$ & $18(9.1 \%)$ & $199(100 \%)$ & \\
\hline
\end{tabular}

Table 4: Total LDL-C level of patients at various age group

\begin{tabular}{|c|c|c|c|c|c|c|c|c|}
\hline \multirow{2}{*}{\multicolumn{2}{|c|}{ Age Group }} & \multicolumn{5}{|c|}{ Low density lipoprotein (mg/dL) } & \multirow{2}{*}{ Total } & \multirow{2}{*}{ Mean LDL-C } \\
\hline & & $<\mathbf{1 0 0}$ & $100-129$ & 130-159 & $160-189$ & $\geq 190$ & & \\
\hline \multirow{2}{*}{ 25-35 years } & $\mathrm{F}$ & $5(2.51 \%)$ & $3(1.5 \%)$ & $1(0.5 \%)$ & $2(1.0 \%)$ & $2(1.0 \%)$ & $13(6.53 \%)$ & \multirow{2}{*}{129.21} \\
\hline & M & $3(1.5 \%)$ & $4(2.01 \%)$ & $5(2.51 \%)$ & 0 & $1(0.5 \%)$ & $13(6.53 \%)$ & \\
\hline \multirow{2}{*}{ 36-45 years } & $\mathrm{F}$ & $7(3.51 \%\}$ & $13(6.53 \%)$ & $3(1.5 \%)$ & $2(1.0 \%)$ & $1(0.5 \%)$ & $25(12.56 \%)$ & \multirow{2}{*}{127.96} \\
\hline & M & $9(4.52 \%)$ & $10(5.02 \%)$ & $6(3.01 \%)$ & $3(1.5 \%)$ & $3(1.5 \%)$ & $30(15.07 \%)$ & \\
\hline \multirow{2}{*}{ 46-55 years } & $\mathrm{F}$ & $9(4.52 \%)$ & $9(4.52 \%)$ & $6(3.01 \%)$ & $4(2.01 \%)$ & 0 & $28(14.07 \%)$ & \multirow{2}{*}{120.00} \\
\hline & M & $11(5.52 \%)$ & $8(4.02 \%)$ & $9(4.52 \%)$ & $2(1.0 \%)$ & 0 & $30(15.07 \%)$ & \\
\hline \multirow{2}{*}{ 56-65 years } & $\mathrm{F}$ & $8(4.02 \%)$ & $4(2.01 \%)$ & $1(0.5 \%)$ & $2(1.0 \%)$ & 0 & $15(7.53 \%)$ & \multirow{2}{*}{104.07} \\
\hline & M & $9(4.52 \%)$ & $9(4.52 \%)$ & $2(1.0 \%)$ & 0 & 0 & $17(8.54 \%)$ & \\
\hline \multirow{2}{*}{$\geq 66$ years } & $\mathrm{F}$ & $4(2.01 \%)$ & $4(2.01 \%)$ & $1(0.5 \%)$ & 0 & 0 & $9(4.52 \%)$ & \multirow{2}{*}{112.47} \\
\hline & M & $10(5.02 \%)$ & $3(1.5 \%)$ & $6(3.01 \%)$ & 0 & 0 & $19(9.54 \%)$ & \\
\hline Total & & $71(35.6 \%)$ & $64(32.1 \%)$ & $4020.1 \%$ ) & $15(7.53 \%)$ & $7(3.51 \%)$ & $199(100 \%)$ & \\
\hline
\end{tabular}

dL with minimum detected level was $102.0 \mathrm{mg} / \mathrm{dL}$ and maximum $588.0 \mathrm{mg} / \mathrm{dL}$. Mean value of blood glucose level at different age group is tabulated in table 2. Uncontrolled blood glucose level $(>200 \mathrm{mg} / \mathrm{dL})$ was detected in male $(\mathrm{n}=109,54.7 \%)$ than in female $(\mathrm{n}=90,45.3 \%)$. Similarly uncontrolled blood glucose level was observed in the 4655 age group $(\mathrm{n}=35,17.58 \%)$ followed by $36-45$ age group $(\mathrm{n}=25,12.56 \%)$.

Lipid profile was analysed among these patients with type 2 diabetes mellitus. Mean value of total cholesterol level at different age group is shown in table 3. Majority of the patients $(\mathrm{n}=138,69.3 \%)$ had desirable cholesterol level. High level of total cholesterol ( $\geq 200 \mathrm{mg} / \mathrm{dL}$ ) was seen male than in females. As the age increases total cholesterol was below $200 \mathrm{mg} / \mathrm{dL}$ in larger percentage than in younger age group. Only $5.01 \%$ of age 55 years had total cholesterol level $>200 \mathrm{mg} / \mathrm{dL}$. Similarly highest mean cholesterol level was observed in the age group of 36-45 years $(201.48 \mathrm{mg} /$ $\mathrm{dL}$ ). Approximately 36 percent of the patients were found to have optimal level of serum LDL cholesterol; 32.1 $\%$ had near optimal/ above optimal level of serum LDL cholesterol; 201.1\% had borderline high; 7.53\% had high
LDL cholesterol level where as $3.51 \%$ had very high level of serum LDL cholesterol. (Table 4) Mean LDL-C was highest in $25-35$ years age group $(129.21 \mathrm{mg} / \mathrm{dL})$ and lowest in 55-65 years age group $(104.07 \mathrm{mg} / \mathrm{dL})$.

Most of the patients had normal serum TG level $(n=92$, $46.23 \%) ; 56$ (28.14\%) had borderline high serum TG level; 45 (22.61\%) had a high serum TG levels where as 6 (3.01\%) had very high level of serum Triglyceride. (Table 5) Extremely high level of triglyceride level was observed in male younger than 45 years of age. Mean triglyceride level was highest at the age group of 36-45 years (267.28 $\mathrm{mg} / \mathrm{dL}$ ) and normal level was observed in the patient older than 55 year of age. HDL-C was lower than normal in 119 (64\%) of the studied population. Ten patients had more than $60 \mathrm{mg} / \mathrm{dl}$ of HDL-C whereas 65 (33\%) patients had normal level of HDL-C.

In correlation studies, cholesterol showed significant correlation with TG $(\mathrm{P}<0.001)$, LDL-C $\quad(\mathrm{P}<0.001)$. Triglyceride showed a significant negative correlation with HDL-C $(\mathrm{P}<0.01)$, while a highly significant positive 
Table 5: Triglyceride level of patients at various age group

\begin{tabular}{|c|c|c|c|c|c|c|c|}
\hline \multirow{2}{*}{\multicolumn{2}{|c|}{ Age Group }} & \multicolumn{4}{|c|}{ Triglyceride (mg/dl) } & \multirow{2}{*}{ Total } & \multirow{2}{*}{$\begin{array}{c}\text { Mean Triglyceride } \\
\text { (mg/dL) }\end{array}$} \\
\hline & & \multirow{2}{*}{$\begin{array}{l}<\mathbf{1 5 0} \\
6(3.01 \%)\end{array}$} & \multirow{2}{*}{$\begin{array}{r}\frac{150-199}{3(1.5 \%)}\end{array}$} & \multirow{2}{*}{$\begin{array}{l}200-499 \\
4(2.01 \%)\end{array}$} & \multirow{2}{*}{$\frac{\geq \mathbf{5 0 0}}{0}$} & & \\
\hline \multirow{2}{*}{ 25-35 years } & $\mathrm{F}$ & & & & & $13(6.53 \%)$ & \multirow{2}{*}{275.07} \\
\hline & M & $4(2.01 \%)$ & $1(0.5 \%)$ & $5(2.51 \%)$ & $3(1.5 \%)$ & $13(6.53 \%)$ & \\
\hline \multirow{2}{*}{$36-45$ years } & $\mathrm{F}$ & $17(8.54 \%)$ & $6(3.01 \%)$ & $2(1.0 \%)$ & 0 & $25(12.56 \%)$ & \multirow{2}{*}{267.28} \\
\hline & M & $7(3.51 \%)$ & $7(3.51 \%)$ & $13(6.53 \%)$ & $3(1.5 \%)$ & $30(15.07 \%)$ & \\
\hline \multirow{2}{*}{ 46-55 years } & $\mathrm{F}$ & $13(6.53 \%)$ & $12(6.03 \%)$ & $3(1.5 \%)$ & 0 & $28(14.07 \%)$ & \multirow{2}{*}{237.84} \\
\hline & M & $9(4.52 \%)$ & $8(4.02 \%)$ & $13(6.53 \%)$ & 0 & $30(15.07 \%)$ & \\
\hline \multirow{2}{*}{ 56-65 years } & $\mathrm{F}$ & $9(4.52 \%)$ & $3(1.5 \%)$ & $3(1.5 \%)$ & 0 & $15(7.53 \%)$ & \multirow{2}{*}{125.21} \\
\hline & M & $11(5.52 \%)$ & $4(2.01 \%)$ & $2(1.0 \%)$ & 0 & $17(8.54 \%)$ & \\
\hline \multirow{2}{*}{$\geq 66$ years } & $\mathrm{F}$ & $8(4.02 \%)$ & $1(0.5 \%)$ & 0 & 0 & $9(4.52 \%)$ & \multirow{2}{*}{118.11} \\
\hline & M & $8(4.02 \%)$ & $11(5.52 \%)$ & 0 & 0 & $19(9.54 \%)$ & \\
\hline Total & & $92(46.23 \%)$ & $56(28.14 \%)$ & $45(22.61 \%)$ & $6(3.01 \%)$ & $199(100 \%)$ & \\
\hline
\end{tabular}

Table 5: Correlation studies between serum lipid profile variables of diabetic patients

\begin{tabular}{lcccc}
\hline & Cholesterol & HDL-C & LDL-C & Triglyceride \\
\hline Cholesterol & & .844 & .001 & $<0.01$ \\
\hdashline HDL-C & .844 & & .297 & $<0.01$ \\
\hline LDL-C & $<0.01$ & .297 & & $<0.001$ \\
\hdashline Triglyceride & $<0.01$ & $<0.01$ & $<0.01$ & \\
\hline
\end{tabular}

**. Correlation is significant at the 0.01 level (2-tailed).

correlation was observed with Cholesterol and HDL-C $(\mathrm{P}<0.001)$. However, HDL-C showed a negative correlation with LDL-C and Cholesterol and triglyceride $(\mathrm{P}<0.01)$. (Table 6)

\section{DISCUSSION}

Lipid profile varies and is highly associated with diabetes mellitus and both are important parameters for dyslipidemia, hypertension, hyperinsulinemia and coronary artery disease. Accelerated coronary and peripheral vascular atherosclerosis is very common and serious chronic complications of long term diabetes mellitus. Along with other risk factors such as hypertension, smoking, obesity etc. increasing importance has been given to dyslipidemia in the causation of accelerated atherosclerosis. ${ }^{17}$ Dyslipidemia as a metabolic abnormality is frequently associated with diabetes mellitus. Its prevalence is variable depending on the type and severity of diabetes, glycaemic control, nutritional status, age and other factors. The most characteristic lipid abnormality in diabetics is hypertriglyceridemia and low HDL cholesterol with or without associated increased in serum total and LDL cholesterol. $^{18,19}$

In our study, the most common abnormality detected in T2DM elevated low density lipoprotein (64.4\%) followed by low serum HDL cholesterol level (62\%). The next common abnormalities being increase in serum TG level (53.7\%) and hypercholesterolemia (30.7\%). Fifty percent patients had normal BMI; 28\% were overweight and 22\% of patients being overtly obese.

A study by Packard et al., reported that reduced HDL-C as a powerful predicator for premature coronary heart diseases. ${ }^{20}$ According to Goldberg HDL-C us converted to VLDL-C particles, and denser LDL particles acquire a large proportion of these HDL esters. This process decreases the HDL-C level. ${ }^{21}$ Beside, HDL-C is a ready substrate for hepatic lipase which converts it into smaller particles, which are readily cleared from the plasma. ${ }^{15,22}$ As with the triglycerides, improvement in glycaemic control leads to an increase in the levels of HDL-C, and suggest the evidence for a role for poor glycaemia in decreasing the level of this lipoproteins.

In our study hypertriglyceridaemia was quite common, seen in $53.7 \%$ among study population. Body Mass Index was increased in almost half of the patients. Other researchers also associated the high triglyceride level to the poor glycaemic control of diabetes and obesity. ${ }^{15,23}$ Decrease of TG level has been observed with improvement in glycemic control. Abbate and Brunzell reported that the increase in triglycerides in poorly controlled patients was related to the decrease of activities of adipose tissue and muscle lipoprotein lipase activity. ${ }^{24}$

Epidemiological study has shown evidence for relationship of serum lipid profile with the CAD risk. In Multiple Risk Factor Intervention Trial (MRFIT), CAD risk declined with progressive lower serum cholesterol level. ${ }^{25}$ Further supportive relationship between CAD risk and dyslipidemia comes from various recent primary and secondary prevention trials with lipid lowering therapy, for example, the HEART PROTECTION STUDY (HPS) ${ }^{26}$ has shown that lipid lowering with statin therapy is efficacious in patients with diabetes to reduce the risk of CAD. Similarly, the Pravastatin or Atorvastatin Evaluation and InfectionThrombolysis in Myocardial Infarction 22 (PROVE IT) trial has demonstrated that intensive LDL cholesterol lowering will reduce the major coronary events. ${ }^{27}$ The NCEP ATP III guidelines recommend a LDL cholesterol goal of $<100 \mathrm{mg}$ / 
dl in Type 2 Diabetic patients. ${ }^{28}$ However, on the basis of recent landmark studies, the recommendation for the optimal goal is $<70 \mathrm{mg} / \mathrm{dl}$, whereas $<100 \mathrm{mg} / \mathrm{dl}$ is considered as minimal goal for therapy. ${ }^{29,30}$ Recent other trials, nonetheless, indicate that for every $1.0 \%$ reduction in LDL cholesterol levels, the relative risk for major coronary events is reduced by $1.0 \%$ approx. ${ }^{31,32}$ Framingham study ${ }^{33,34}$ has demonstrated the correlation between low HDL cholesterol and $\mathrm{CAD}$ as an independent risk factor. Also the elevated TG level has recently become an independent predictor of CAD risk. ${ }^{35-37}$

\section{CONCLUSION}

The present study supports that diabetes is associated with higher incidence of dyslipidemia. This association may be the mechanism by which T2DM is associated with increased CAD risk. The presence of T2DM with any other risk factors is sufficient to consider an indication for lipid lowering therapy as a primary prophylaxis for CAD that includes both lifestyle modifications and statin therapy. The presence of both dyslipidemia and T2DM warrants a more intensive drug therapy in addition to lifestyle modification to achieve successfully the NCEP ATP III recommendations.

\section{Conflict of interest: None}

\section{REFERENCES}

1. Haffner SM, Lehto S, Ronnemaa T, Pyorala L, Laakso M. Mortality from coronary heart disease in subjects with type 2 diabetes and in non diabetic subjects with or without prior myocardial infarction. New Engl J Med 1998; 339:229-34. Crossref

2. Smith JW, Marcus FI, Serokman R. Prognosis of patients with diabetes mellitus after acute myocardial infarction. Am J Cardiol 1984;S4:718-21. Crossref

3. Miettinem H, Lehto S, Salomaa $U$ et al. for the FINMONICA Myocardial Infarction Register Study Group: Impact of diabetes on mortality after first myocardial infarction. Diabetes care 1998;21:6975. Crossref

4. American Diabetes Association. Standards of Medical Care in Diabetes. Diabetes Care 2007;30:4-41. Crossref

5. Joshua A, Becham B, Libby P. Diabetes and Atherosclerosis. J Amer Med Assoc 2002;287:2570-81. Crossref

6. Frank B, Stampfer J, Steven M. Elevated risk of cardiovascular disease prior to clinical diagnosis of type 2 diabetes. Diabetes Care 2002;25:1129-34. Crossref

7. Sridhar RG. Diabetes in India: snapshot of a panorama. Current Science 2002;83:1-2.

8. Car J, Patel H, Majeed A. Diabetes care in developing countries. Canadian Med Assoc J 2004;176:209-12. Crossref
9. Khatit M, Quazi S. Risk factors of type 2 diabetes mellitus in rural wardha: a community bared study. International Journal of Diabetes in Developing countries 2008; 28:79-82. Crossref

10. Analava M, Bhattacharya D, Reys. Dietary Influence on Type 2 Diabetes (NIDDM). J Hum Ecod 2007;21:139-47.

11. Goldfine and Beckman: Life and Death in Denmark: Lesson About Diabetes and Coronary Heart Disease. Circulation 2008;117:1914-7. Crossref

12. Kunsisto J, Mykknen L, Laakso M. NIDDM and its metabolic control predict coronary heart disease in elderly subjects. Diabetes 1994;43:960-7. Crossref

16. Mozaffarian D, Martijn B, Alberto A, Mer J. Trans Fatty Acids and cardiovascular diseases. New Engl J Med 2006;354:1601-13. Crossref

13. Ronald M, Krauss M. Lipids and Lipoproteins in Patients with type 2 Diabetes. Diabetes Care 2004;27:1496-504. Crossref

14. National Institutes of Health. Clinical guidelines on the identification, evaluation, and treatment of overweight and obesity in adults - the evidence report. Obes Res 1998;6(Suppl 2):51S -210S. Crossref

15. Dunn FL. Treatment of lipid disorders in diabetes mellitus. Med Clin North America 1988;72. Crossref

16. Nau DP, Mallya U. Sex disparity in the management of dyslipidemia among patients with type 2 diabetes mellitus in a managed care organization. Am J Manag Care. 2005;11:69-73. Crossref

17. Goldberg RB. Lipid disorders in diabetes. Diabetes Care 1981;4:561. Crossref

18. Taskinen MR. Hyperlipidemia in diabetes. Clin Endocrinol Metab 1990;4:743.

19. Packard C, Nunn A, Hobbs R. High density lipoprotein: guardian of the vascular system. Inter J Clin Pract. 2002;56:761-71. Crossref

20. Goldberg IJ. Diabetic dyslipidemia: causes and consequences. J Clin Endo Metab 2001;8:965-71. Crossref

21. Elinasri HA, Ahmed AM. Patterns of lipid changes among type 2 diabetes patients in Sudan. Eastern Mediter Health J. 2008;14:2.

22. Mooradian AD. Dyslipidemia in type 2 diabetes mellitus. Nat Clin Pract Endocrin Metab. 2009;5:150-159. doi: 10.1038/ ncpendmet1066. Crossref

23. Abbate SL, Brunzell JD. Pathophysiology of hyperlipidemia in diabetes. J Cardiovasc Pharmacol. 1990;16:1-7. Crossref

24. Stamler J, Wentworth D, Neaton JD. Is relation between serum cholesterol and risk of premature death from coronary heart disease 
continuous and graded? Findings in 356,222 primary screenees of multiple risk factor intervention trail (MRFIT). J Amer Med Assoc 1985;256:2823-8. Crossref

25. Heart Protection Study collaborative Group, MRC/BHF. Heart Protection Study of cholesterol lowering with simvastatin in 20,536 high risk individuals: a randomized placebo-controlled trial. Lancet 2002;360:7. Crossref

26. Cannon $\mathrm{CP}$, Braunwals E, McCabe $\mathrm{CH}$ et al. Pravastatin or Atorvastatin Evaluation and Infection Therapy- Thrombosis in Myocardial Infarction 22 Investigators. Intensive versus moderate lipid lowering with statins after acute coronary syndromes. New Engl J Med 2004;350:1495-504. Crossref

27. Executive summary of the Third Report of the National Cholesterol Education Programme (NCEP) Expert Panel on Detection, Evaluation and Treatment of High Blood Cholesterol in Adults (Adult Treatment Panel III). J Amer Med Assoc 2001;285:2487-97.

28. Grundy SM, Cleeman JI et al.. Implications of recent clinical trials for the National Cholesterol Education Programme Adult Treatment Panel III Guidelines. Circulation 2004;110:227-39. Crossref

29. Waters DD, Guyton JR, Herrington DM, McGowan MP, Wenger NK, Shear C. TNT Steering Committee members and Investigators. Treating to New Targets (TNT) Study: Does lowering low density lipoprotein cholesterol levels below currently recommended guidelines yield incremental clinical benefit? Amer J Cardiol 2004;93:158-8. Crossref
30. Randomised trial of cholesterol lowering in 4444 patients with coronary heart disease: the Scandinavian Simvastatin Survival Study (4S). Lancet 1994;344:1383-9. Crossref

31. The Long Term Intervention with Pravastatin in Ischemic Disease (LIPID) Study Group. Prevention of cardiovascular events and death with Pravastatin in patients with coronary heart disease and a broad range of initial cholesterol levels. New Engl J Med 1998;339:134957. Crossref

32. Castelli WP, Garrison RJ, Wilson PW et al. Incidence of coronary heart disease and lipoprotein cholesterol levels: the Framingham Study. J Amer Med Assoc 1986;256:2835-38. Crossref

33. Castelli WP. Cholesterol and lipids in the risk of coronary artery disease: the Framingham Heart Study. Canadian J Cardiol 1988;4(suppl):5A-10A. Crossref

34. Hokanson J E, Austin M A. plasma triglyceride level is a risk factor for cardiovascular disease independent of high density lipoprotein cholesterol level; a meta-analysis of population- based prospective studies. J Cardiovac Res 1996; 3:213-29. Crossref

35. Castelli W P. Epidemiology of triglycerides: a view from Framingham. Amer J Cardiol 1992; 70(suppl):3H-9H. Crossref

36. Assman G, Schulte H. Relation of high density lipoprotein cholesterol and triglyceride to incidence of atherosclerotic coronary artery disease (the PROCAM experience). Amer J Cardiol 1992;70:733-7. Crossref 